\title{
AGGLUTINATED CONICAL FORAMINIFERA (ORBITOLINIDAE, COSKINOLINIDAE) FROM THE UPPER CRETACEOUS (CAMPANIAN) OF GREECE, WITH DESCRIPTION OF PARACOSKINOLINA KLOKOVAENSIS N. SP.
}

\author{
Felix Schlagintweit
}

\begin{abstract}
Received: 27 March 2021 / Accepted: 3 May 2021 / Published online: 17 May 2021
Abstract An assemblage of agglutinated conical foraminifera including Lepinoconus chiocchinii Cruz-Abad et al., Calveziconus lecalvezae Caus \& Cornella, Paleodictyoconus sp., and Paracoskinolina klokovaensis n. sp. are described from the upper lower-middle Campanian of Klokova Mountain of the Gavrovo-Tripolitza Zone, SW continental Greece. With the presence of one rafter in the marginal zone, the new species $P$. klokovaensis compares to the Lower Cretaceous species Paracoskinolina arcuata (Arnaud-Vanneau) that is distinguished by its cylindroconical test morphology and much larger size. The assemblage occurs in inner platform carbonates associated with other foraminifers such as dicyclinids, and Accordiella conica Farinacci. Representatives of the genus Paracoskinolina were so far only reliably reported from the Upper Berriasian-Albian interval. This new record suggests that the genus either survived the larger benthic foraminifera extinction event associated with the Cenomanian - Turonian boundary anoxic event, or may be an example of an Elvis taxon or homoplasy.
\end{abstract}

Keywords: Late Cretaceous, Larger Benthic Foraminifera, Dictyoconinae, taxonomy, biostratigraphy

\section{INTRODUCTION}

Larger agglutinated conical foraminifers (Orbitolinidae, Coskinolinidae) are widespread in Lower Cretaceous shallow-water platform carbonates (e.g., ArnaudVanneau, 1980; Clavel et al., 2014). Records from the Upper Cretaceous (post-Cenomanian) are restricted to a distinctly reduced number of genera and species (Gendrot, 1968; Moullade and Viallard, 1973; Neumann, 1978; Bilotte, 1974; Luperto Sinni and Martin-Chivelet, 1999; Schlagintweit et al., 2016; Luger, 2018; Schlagintweit and Rashidi, 2021). In the Adriatic-Dinaridic carbonate platforms, occurrences of Upper Cretaceous orbitolinids are known, where these have been described in open nomenclature (Fleury, 1970; Luperto Sinni, 1976). From the "lower Senonian" of Greece, Orbitolinid foraminifers have been described and illustrated by Fleury (1970). Referring to the locality Mount Klokova, and their description in open nomenclature, they have been grouped as "K orbitolinidés". Fleury (1970, p. 36) noted that the observed forms could not be assigned to any known species. In fact, three different forms were described as Orbitolinidae gen. ind., Coskinolina sp., and Dictyoconus sp. This assemblage of agglutinated conical foraminifers is herein taxonomically reassessed, including a description of Paracoskinolina klokovaensis n. sp. It contributes to the still relatively poor knowledge of this group of larger benthic foraminifera from Upper Cretaceous shallow-water carbonates, and their distribution within the peri-Mediterranean realm.

\section{GEOLOGICAL SETTING}

The Gavrovo-Tripolitza Platform (Dercourt, 1964) belongs to the external Hellenides and crops out in the western part of continental Greece, the Peloponnesus, and some islands (Zambetakis-Lekkas and Alexopoulos, 2007, Fig. 1). Composed mainly of Upper Cretaceous and Eocene shallow-water carbonates, these sedimentary rocks form the mountains of Varassova and Klokova in south Akarnania, as well as the Gavrovo massif (Ori Valtou) further north, and a discontinuous chain of smaller massifs at the Peloponnesus western edge, from Skolis to Pylos-Methoni (Auboin et al., 1958; Fleury, 1970, 1980; Bernier and Fleury, 1980; Mavrikas, 1993). In a greater paleotectonic context, the Gavrovo-Tripolitza Zone represents "an Adria-derived" (Nirta et al., 2020) or "South Adriatic" unit (Zelic et al., 2010), so that the successions and their fossil biota can be compared with Apulia, and the "Senonian" occurrences of orbitolinids there (Luperto Sinni, 1976). The material studied herein comes from Klokova Mountain in Akarnania, a region of westcentral Greece. The locality has been studied in detail by Fleury (1970), distinguishing eight lithologic units. Orbitolinid foraminifers have been observed in the lowermiddle part ( $\sim 60 \mathrm{~m}$ vertical range in Klokova section) (Fleury, 1970, Fig. 1) (Fig. 2). The orbitolinid assemblage occurs in biomicritic (occasional fenestral) limestones, indicating inner platform facies. Accompanying benthic foraminifers include Accordiella conica Farinacci, dicyclinids and Senalveolina aubouini Fleury (Fig. 3). The succession studied by Fleury (1970, p. 93, figs. 28$29,1980)$ is exposed on the southern side of Klokova Mountain along the road between Nafpaktos and Messolonghi. It is also the type-locality of Senalveolina aubouini (Fleury, 1984). The levels with "Orbitolinidés K" 


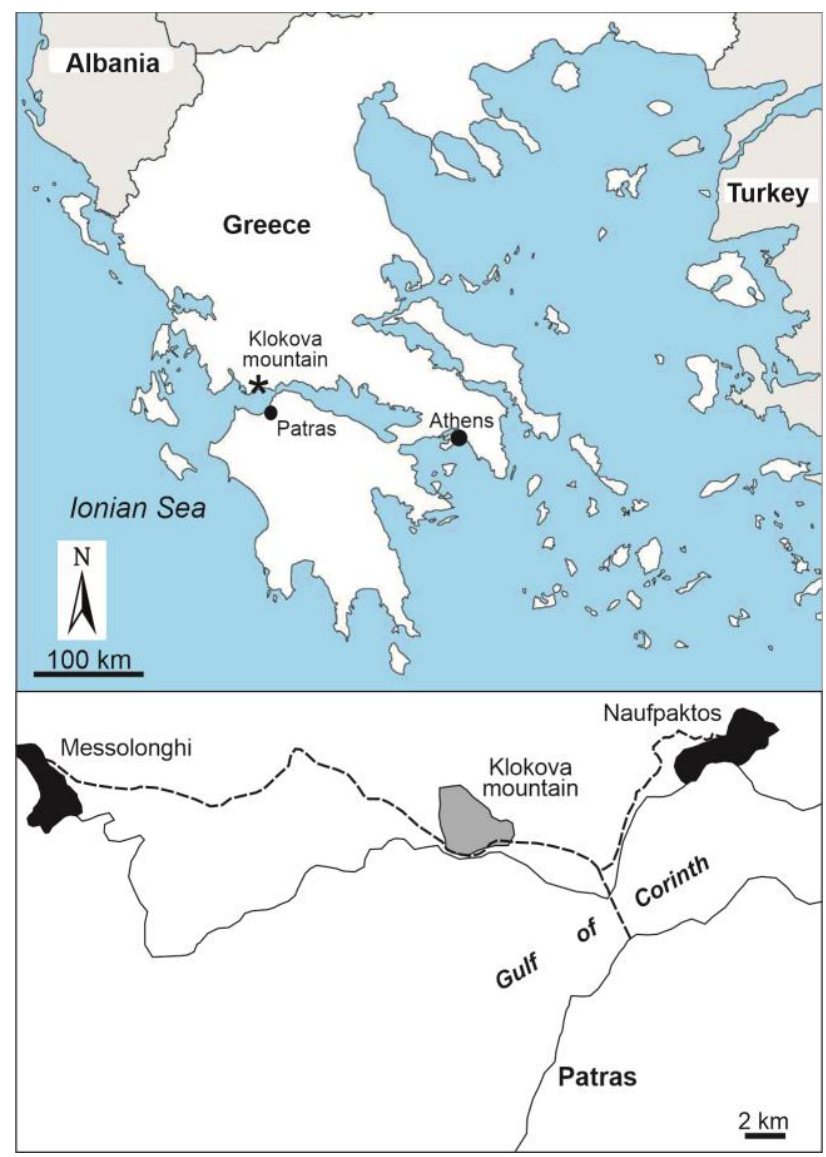

Fig. 1 Geographic sketch map showing the location of Klokova mountains on the opposite side of the Gulf of Corinth facing Patra. This is the type-locality of Paracoskinolina klokovaensis n. sp.

(for Klokova) have been placed into the upper SantonianLower Campanian by Fleury (1980, fig. 8, p. 44). Based on Orbitolinid and other larger benthic foraminifera, they can be assigned to the uppermost lower-middle Campanian (see subchapter Biostratigraphy following the systematic descriptions for details).

\section{MATERIAL AND DEPOSITORY}

The four thin sections containing the illustrated specimens from Klokova Mountain (material from Fleury, 1970, 1980) are hosted by the Paleontology Museum, Department of Geology of Babeş-Bolyai University, Cluj-Napoca, Romania, under the official depository numbers 24307 to 24310 (Table 1). The two specimens illustrated from Brač Island, Croatia, are the property of the Croatian Geological Survey and their repository is currently in the Geological-Paleontological Department of the Croatian Natural History Museum, Demetrova 1, Zagreb, Croatia.

\section{SYSTEMATIC MICROPALEONTOLOGY}

The classification follows Kaminski (2014).

Phylum Foraminifera d'Orbigny, 1826
Class Globothalamea Pawlowski et al., 2013

Order Loftusiida Kaminski \& Mikhalevich, 2004

Suborder Orbitolinina Kaminski, 2004

Superfamily Coskinolinoidea Moullade, 1965

Family Coskinolinidae Moullade, 1965

Remarks: While the family Coskinolinidae is placed in the order Loftusiida by Kaminski (2014), it is included in the order Textulariina by Cruz-Abad et al. (2017).

Genus Lepinoconus Cruz-Abad, Consorti \& Caus, 2017 Lepinoconus chiocchinii Cruz-Abad, Consorti \& Caus, 2017

Fig. 4a, d, g, j

1970 Coskinolina sp. - Fleury, p. 36, pl.1, figs. 5-7.

1976 Urgonina sp. - Luperto Sinni, p. 312, pl. 37, figs. 16.

1976 Paracoskinolina sp. - p. 313, Luperto Sinni, pl. 38, figs. 1-3.

1976 Abradia mosae (Hofker) - p. 316, Luperto Sinni, pl. 41, figs. 1-12.

1993 Orbitolinidés K - Mavrikas, pl. 1, fig. 10.

*2017 Lepinoconus chiocchinii gen. et sp. nov. - CruzAbad et al., p. 348-350, pls. 1-2 (with synonymy)

Table 1. Sample numbers

\begin{tabular}{|l|l|l|}
\hline $\begin{array}{l}\text { Inventory } \\
\text { number }\end{array}$ & Field Number & Collection \\
\hline $\mathbf{2 4 3 0 7}$ & $273-$ GKL39-3357 & $\begin{array}{l}\text { Bucur \& } \\
\text { Schlagintweit }\end{array}$ \\
\hline $\mathbf{2 4 3 0 8}$ & $276-$ GKL43X-3845 & $\begin{array}{l}\text { Bucur \& } \\
\text { Schlagintweit }\end{array}$ \\
\hline $\mathbf{2 4 3 0 9}$ & $276-$ GKL43-511 & $\begin{array}{l}\text { Bucur \& } \\
\text { Schlagintweit }\end{array}$ \\
\hline $\mathbf{2 4 3 1 0}$ & $276-$ GKL43-1780 & $\begin{array}{l}\text { Bucur \& } \\
\text { Schlagintweit }\end{array}$ \\
\hline
\end{tabular}

Remarks: For a detailed description of this monospecific genus see Cruz-Abad et al. (2017). The thick wall (with pseudo-keriotheca) and the aligned pillars are clearly discernible in the Greek specimens (Fig. 4A, D, J). The broken transverse section shown in Fig. 4D has a diameter of $\sim 1.1 \mathrm{~mm}$, slightly larger as the maximum test diameter indicated by Cruz-Abad et al. (2017) as $1.0 \mathrm{~mm}$. Apart from the occurrences in Greece, Italy, and ?Albania (see synonymy in Cruz-Abad et al., 2017), a further occurrence can be added from Brač Island, Croatia, also in association with Calveziconus lecalvezae and Paracoskinolina klokovaensis and at an equivalent stratigraphic position (Gušić and Jelaska, 1990; Cvetko-Tešović et al., 2001).

Superfamily Orbitolinoidea Martin, 1890

Family Orbitolinidae Martin, 1890

Subfamily Dictyoconinae Schubert, 1912

Remarks: Schubert (1912, p. 207) introduced the name Dictyoconinae for a "group" (Gruppe) of agglutinated foraminifers comprising the five genera: Lituonella 


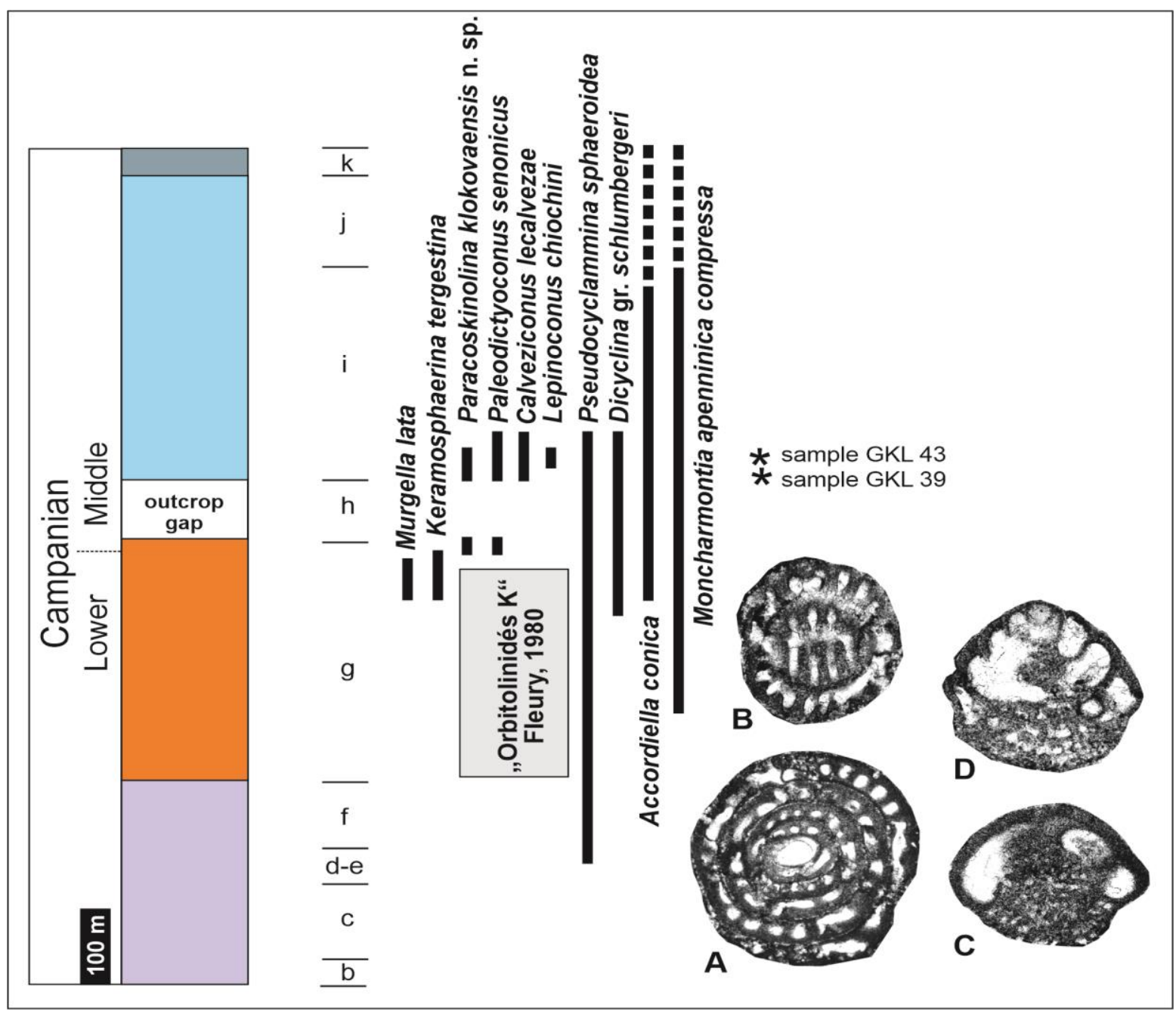

Fig. 2 Upper Cretaceous successions of Klokova Mountain, SW Greece (see Fleury, 1970, fig. 1, for details) with the distribution of some benthic foraminifers (A-B: Senalveolina aubouini Fleury, sample GKL 43; C-D Accordiella conica Farinacci, sample GKL 43x, without scale). Note: the lower/middle Campanian boundary is approximately placed at the LAD of K. tergestina (Frijia et al., 2015, fig. 15). For microfacies of sample GKL 39 see Figure 3.

Schlumberger in Schlumberger and Douvillé, 1905, Coskinolina Stache, 1875, Chapmania Silvestri, 1904, the eponymous Dictyoconus Blanckenhorn, 1900, and Lituola Lamarck, 1804, and suggested that this "row" of taxa represented a stratigraphic succession. With reservation, Schubert (1912) added Conulites Carter, 1861 and Conulina d'Orbigny, 1831. Without going into details about the taxonomic status of these genera, only Dictyoconus is left as a member of this "group". Others are partly junior synonyms of other genera (e.g. Lituonella and Coskinolina), and belong to other families and orders (e.g. Chapmanina). Obviously, the work of Schubert (1912), written in German, was overlooked by Moullade (1965) when he established the new subfamily Dictyconinae. Shortly afterwards, the priority of the name introduced by Schubert (1912) was recognized by Moullade (1966, p. 35). Although both, Schubert (1912) and Moullade (1965) are included in the reference list of Loeblich and Tappan (1987), confusingly, they choose to retain the name Dictyoconinae Moullade, 1965. While some workers correctly used Schubert as author of the subfami- ly (e.g. Arnaud-Vanneau, 1976; Decrouez and Moullade, 1974), many have not questioned Loeblich and Tappan (1987) and follow their incorrect taxonomy (e.g. Mancinelli and Chiocchini, 2006; Vecchio and Hottinger, 2007; Clavel in Granier et al., 2013; Kaminski, 2014; Vicedo et al., 2014; Schlagintweit et al., 2016; Serra-Kiel et al., 2016; Villalonga et al., 2019).

Genus Paleodictyoconus Moullade, 1965

Paleodictyoconus cf. senonicus Moullade \& Viallard, 1973

Figs. 3 pars, $4 b-c$, e-f

1970 Dictyoconus sp. - Fleury, pl. 1, 1?, 4.

*1973 Paleodictyoconus senonicus $\mathrm{n}$. sp. - Moullade and Viallard, p. 338-340, pls. 1-3.

?1976 Paleodictyoconus sp. - Luperto Sinni, p. 315-316, pl. 39, figs. 1-6, pl. 40, figs. 1-4.

1985 Paleodictyoconus senonicus Moullade \& Viallard Bilotte, p. 358, pl. 16, figs. 1-5. 


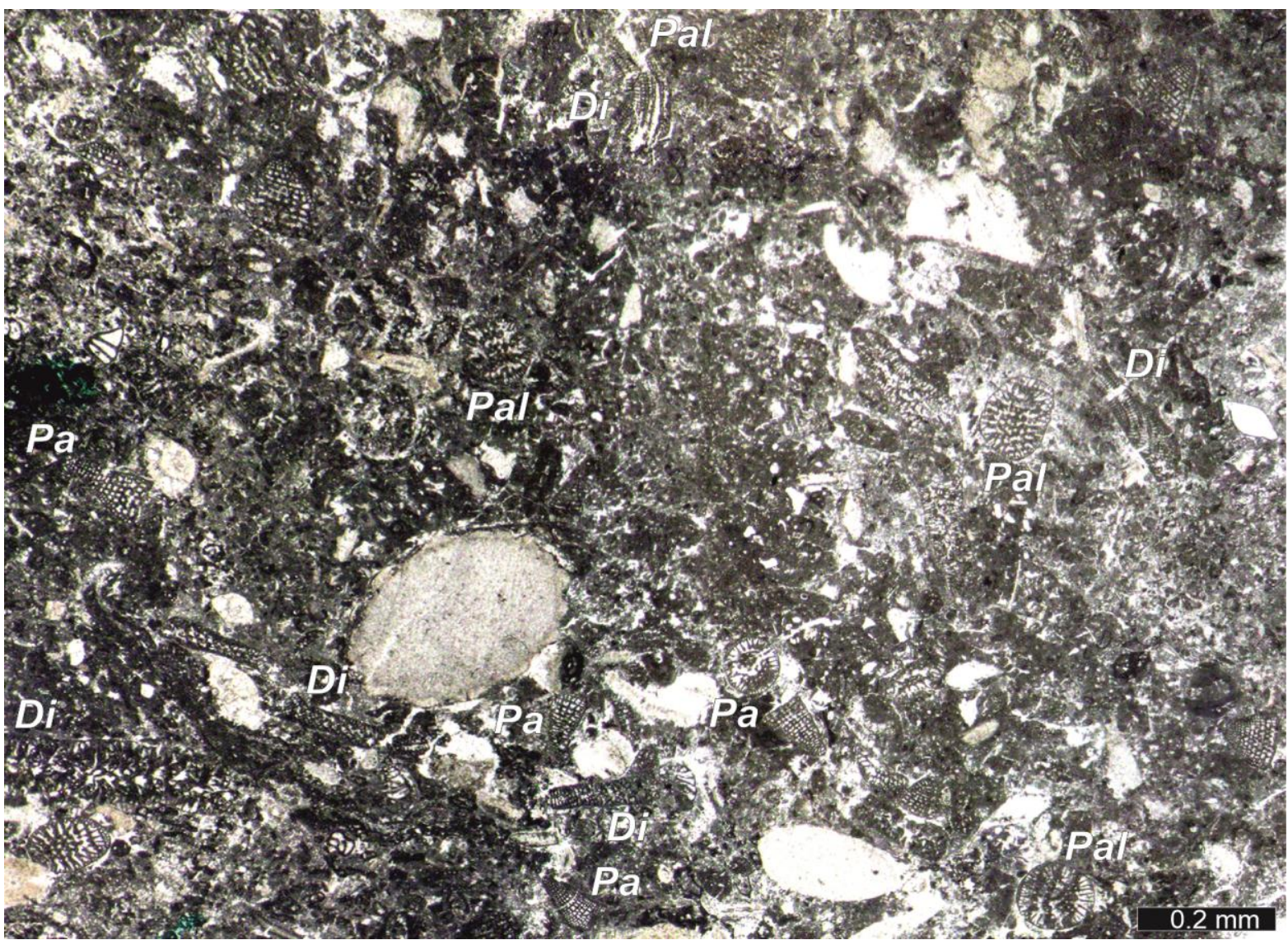

Fig. 3 Upper Cretaceous (middle Campanian) microfacies of sample GKL 39. Pa = Paracoskinolina klokovaensis n. sp., Pal $=$ Paleodictyoconus senonicus Moullade \& Viallard, Di = Dicyclina schlumbergeri Munier-Chalmas.

Remarks: Although Moullade and Viallard (1973, p. 340 , footnote) noted similarities of the specimens illustrated by Fleury (1970) as Dictyoconus sp. with Paleodictyoconus senonicus, they refrained from a concluding assessment because the Greece material lacks axial sections showing the pronounced initial spire, a circumstance also accounting for some reservations expressed herein (cf.). P. cf. senonicus has been observed in association with $P$. klokovaensis in the same samples (Fig. 3). The dimensions of $P$. senonicus are larger (height up to $1.5 \mathrm{~mm}$, diameter up to $1.15 \mathrm{~mm}$ ), there are 1 to 2 rafters (according to Moullade and Viallard, 1973), the test diameter is not increasing continuously from apex to base as in P. klokovaensis, but may decrease later resulting in a bell-shaped outline in axial sections (e.g. Moullade and Viallard, 1973, pl. 1, figs. 1, 5, 8). The pillars of $P$. senonicus, with a tendency to anastomization, are alternating between subsequent chambers (Fig. $4 C, F)$. Last but not least, there are 8-9 chambers per last $0.5 \mathrm{~mm}$ axial length, meaning that the chamber height of $P$. cf. senonicus is reduced compared to $P$. klokovaensis.

Remarks: Bilotte (1985) reported P. senonicus from the lower Campanian of the French Pyrenees. For the orbitolinid occurrences in southern Italy, the exact stratigraphic position is still uncertain (Luperto Sinni, 1976, p. 303, "restano...datati con molta precision"). At the typelocality, P. senonicus occurs in levels with Lacazina elongata Munier-Chalmas \& Schlumberger below and above. This species is reported from the upper Santonianlower Campanian (Gräfe, 2005, fig. 4).

Genus Calveziconus Caus \& Cornella, 1982

Calveziconus lecalvezae Caus \& Cornella, 1982

Fig. 4h-k

1976 Paleodicytoconus sp. - Luperto Sinni, pl. 39, figs. 1-6, pl. 40, figs. 1-4

1981 Calveziconus lecalvezae n. gen., n. sp. - Caus and Cornella, p. 27-34, ps. 1-2.

1985 Calveziconus lecalvezae Caus and Cornella - Bilotte, p. 358, pl. 17, figs. 1-12.

1988 Calveziconus lecalvezae Caus and Cornella - Caus et al., pl. 2, fig. 4.

1988 Calveziconus lecalvezae - Gusič and Jelaska, pl. 2, fig. 8 pars.

1990 Calveziconus lecalvezae - Gusič and Jelaska, pl. 8, fig. 2, pars, 3 , pl. 9 , fig. 1 .

1992 Calveziconus lecalvezae Caus and Cornella Pleničar and Šribar, pl. 4, fig. 6.

2001 Calveziconus lecalvezae Caus and Cornella - Cvetko-Tešovic et al., p.608, fig. 9A.

2007 Calveziconus lecalvezae Caus and Cornella - Velić, pl. 25, figs. 1-4.

2010 Calveziconus lecalvezae Caus and Cornella - Zambetakis-Lekkas, fig. 4.2. 



b
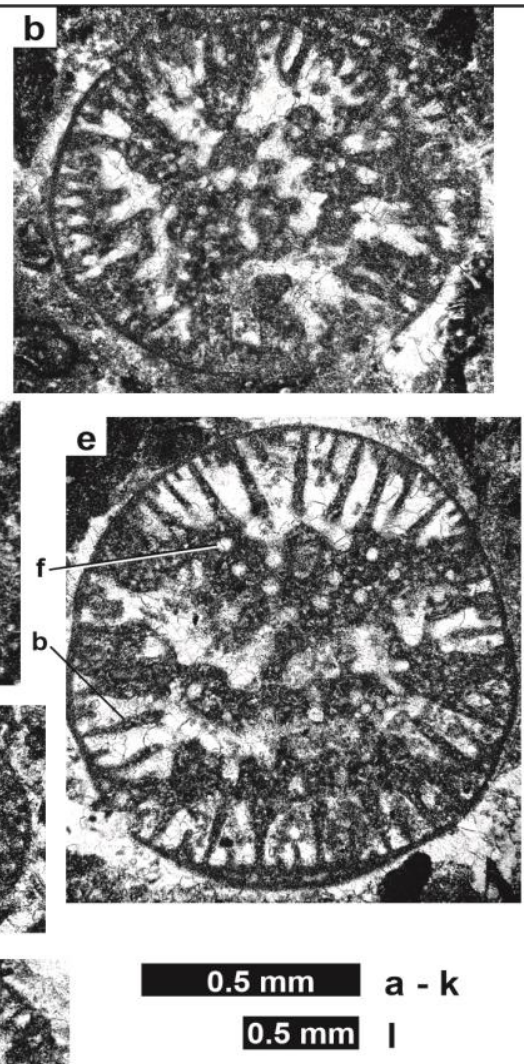
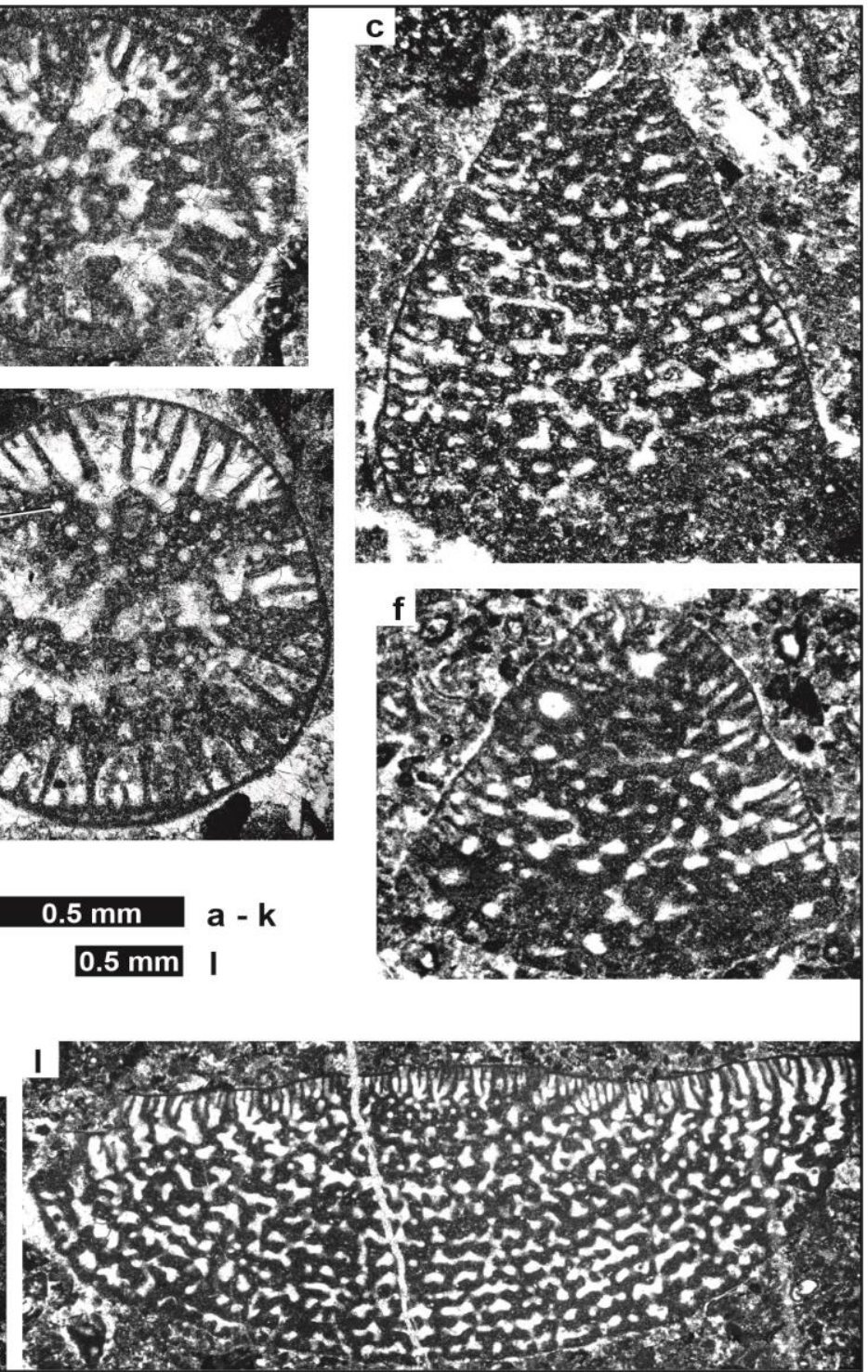

Fig. 4 Coskinolinidae (a, d, g, j) and Orbitolinidae (b-c, e-f, h-i, k-l) from the Campanian of Klokova Mountain SW Greece (a-f, h-l) and Brač Island, Croatia (g). Lepinoconus chiocchinii Cruz-Abad et al. a Oblique section. d Broken transverse section. g, j Subaxial sections. Paleodictyoconus senonicus Moullade \& Viallard b, e Oblique transverse sections. c, f Subaxial sections. Calvezicionus lecalvezae Caus \& Cornella. h, k Oblique sections. i Oblique section passing the biloculine, slightly inclined megalospheric embryo. Dictyoconella complanata Henson. I Oblique section in the plane of compression. Abbreviations: $\mathrm{b}=$ beam, de $=$ deuteroconch, $\mathrm{f}=$ foramen, $\mathrm{p}=$ protoconch, $\mathrm{pi}=$ pillar, $\mathrm{s}=$ septum. Thin sections: GKL $43(\mathbf{a}, \mathbf{j}, \mathbf{i}, \mathbf{l})$, GKL 43x (d, k), GKL 39 (b-c, e, h), GKL 39x (f).

2012 Calveziconus lecalvezae Caus and Cornella - Sokač et al., pl. 19, figs. 7-10.

2013 Calveziconus lecalvezae Caus and Cornella - Molina et al., fig. 8.6 and fig. 8.8 pars.

2015 Calveziconus cf. lecalvezae Caus and Cornella Frijia et al., fig. 8L.

2016 Calveziconus cf. lecalvezae Caus and Cornella Moro et al., fig. $5 \mathrm{c}, \mathrm{f}, \mathrm{o}, \mathrm{p}, \mathrm{t}$, and $\mathrm{u}$.

2019 Calveziconus lecalvezae Caus and Cornella Villalonga et al., p. 20, pl. 1, figs. 1-6, pl. 2, figs. 1-11. 2020 Calveziconus lecalvezae Caus and Cornella - Sha et al., fig. 9d, f, ?g.
Remarks: Rare sections, not allowing a detailed description have been observed in the orbitolinid assemblage of Klokova Mountain. The species has a wide palaeogeographic distribution from Spain, Slovenia, Croatia, Greece, to India (see synonymy). In the original description, Calveziconus has been compared with the genera Orbitolinopsis Henson, Neorbitolinopsis Schroeder, and Abrardia Neumann \& Damotte. Instead, striking structural matches with the Lower Aptian Iraqia Henson can be stated. These comprise the medium-high conical test, a simple, slightly eccentric embryo, a marginal zone with several beams and one rafter, and a reticulate central zone. From the Maastrichtian Simsima Formation of 

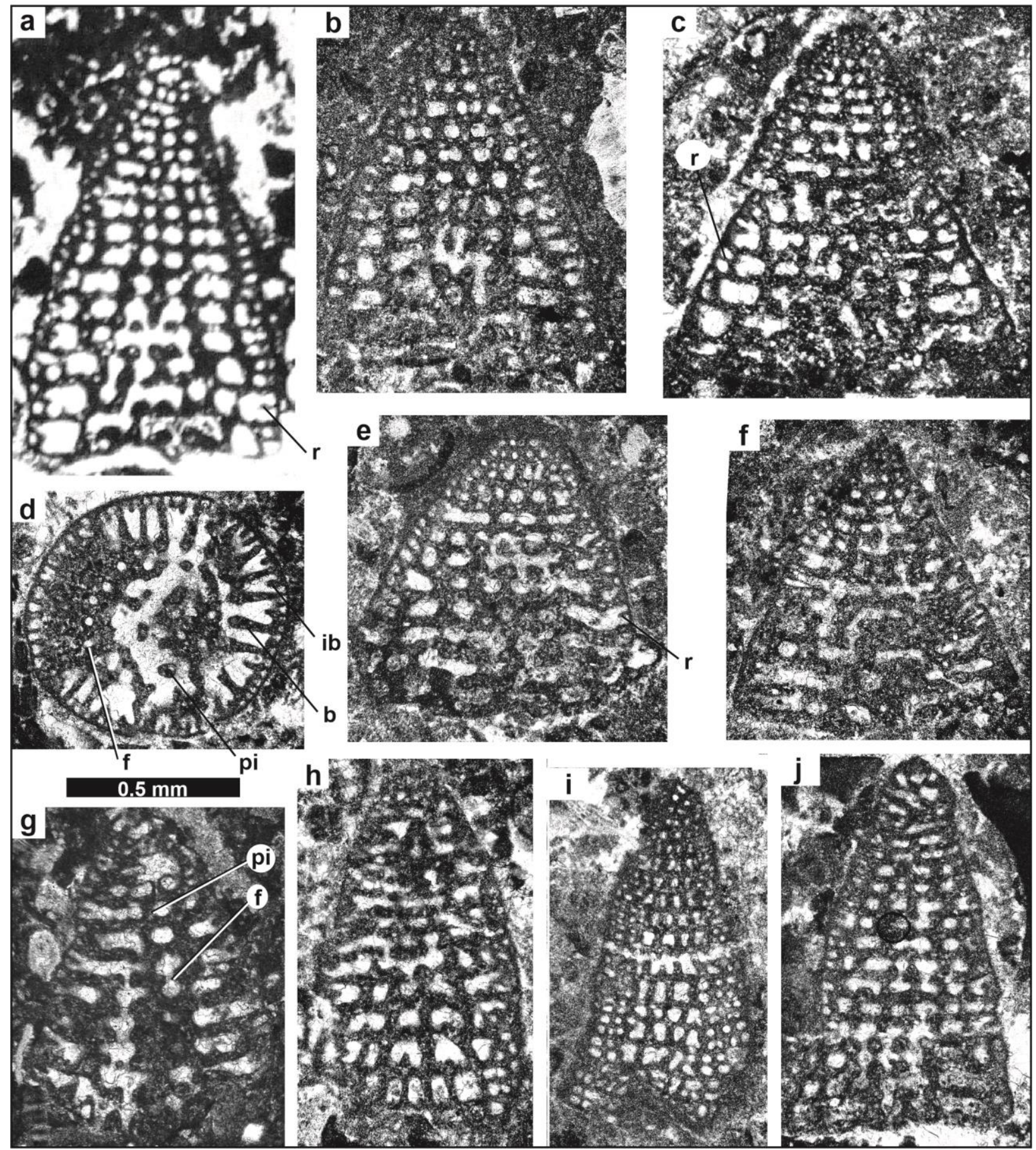

Fig. 5 Paracoskinolina klokovaensis n. sp., from the late early-middle Campanian of Mount Klokova, SW Greece (a-f, h-j) and Brač Island, Croatia (g). a Axial section. b-c, f-g Subaxial sections. d Oblique transverse section. h Oblique section. i Tangential section. $\mathbf{j}$ Axial section, holotype specimen. Abbreviations: $\mathrm{b}=$ beam, $\mathrm{f}=$ foramen, $\mathrm{ib}=$ intercalary beam, $\mathrm{pi}=\mathrm{pillar}, \mathrm{r}=\mathrm{rafter}$. Thin sections: a GKL 39 (1754) (from Fleury, 1970, pl. 1, fig. 2), b-j GKL 39 (3357).

Qatar, Whittaker et al. (1998) reported "Calveziconus" sp. nov. showing a complex marginal zone (with up to four orders of rafters, pl. 42, fig. 3 therein) and pillars in the central zone (pl. 42, figs. 4-5 therein); this form is different from Calveziconus Caus \& Cornella. More sections are needed for a better characterization of the Middle East form.

Genus Dictyoconella Henson, 1948

Type species: Dictyoconella complanata Henson, 1948
Dictyoconella complanata Henson, 1948

Fig. 41

*1948 Dictyoconella complanata n. gen., n. sp. - Henson, p. 25 , plate 6 , figs. $2-3,16$, pl. 10 , fig. 14 .

1998 Dictyoconella complanata Henson - Whittaker et al., pl. 47, figs. 4-6.

2021 Dictyoconella complanata Henson - Schlagintweit and Rashidi, p. 7, figs. 2a-b pars, 3-4 (with synonymy). 
Remarks: A single specimen $(\sim 4 \mathrm{~mm}$ in diameter $)$ in a slightly oblique section parallel to the plane of test compression. D. complanata has so far been reported from Maastrichtian strata; the occurrence in the Campanian of Greece extends its stratigraphic record and also the previously assumed palaeogeographic restriction to the Arabian Plate (see Schlagintweit and Rashidi, 2021).

Subfamily Dictyorbitolininae Schroeder in Schroeder et al., 1990

Genus Paracoskinolina Moullade, 1965

Type species: Coskinolina sunnilandensis Maync, 1950

Paracoskinolina klokovaensis n. sp.

Figs. 3 pars, 5a-j, 6a

1970 Dictyoconus sp. - Fleury, p. 37, pl. 1, figs. 2-3.

Origin of the name: Referring to the type-locality of the new species: Mount Klokova in western Greece.

Holotype: Subaxial section shown in Fig. 5a.

Paratypes: Specimens illustrated in Fig. 5b-j.

Horizon and locality: late early-middle Campanian of Mount Klokova, SW Greece.

Description: Medium- to high-conical test displaying smooth surface and plane to slightly convex base. The test height may slightly exceed the diameter, often the latter accounts for about $2 / 3$ of the former. A small initial spire is barely visible (Fig. 5a, i); the embryo has not been observed. Each adult rectilinear chamber (up to 16 in adult specimens) is subdivided into a marginal and central zone. The exoskeleton of the marginal zone consists of one horizontal partition (rafter) (e.g. Fig. 5b) and 1 to 2 intercalary beams between the vertical main partitions (beams). The latter are straight and slightly but continuously widening inwards and exceed the length of the intercalary beams distinctly (about 4 times). The pillars of the central zone are aligned between subsequent chambers as visible in axial sections (Fig. 5b). In oblique section, they appear slightly offset against each other (Fig. $5 \mathrm{e}$ ). The pillars are widened at the base and top and may have a string-of-pearls appearance (Fig. 5a). There are $\sim 5$ pillars in axial section for a test diameter of $0.5 \mathrm{~mm}$. The foramina of the central zone are, like the pillars, aligned; the outermost foramina (towards the marginal zone) are arranged in a circle (Fig. 5d, left side). The wall is finely agglutinated.

\section{Dimensions (in mm):}

Test diameter: 0.85-1.1 mm

Test height: $0.75-1.2 \mathrm{~mm}$

Number of chambers per last $0.5 \mathrm{~mm}$ cone axis: 6-7

Apical angle: $\sim 28$ to 55 degrees

Remarks: From the upper Albian-Cenomanian shallowwater carbonates of the Argolis Peninsula of Greece, Decrouez and Moullade (1974) described four new Orbitolinidae, which amongst them Paracoskinolina fleuryi. This taxon does not possess aligned pillars, instead alternating main partitions, and is therefore excluded from the genus Paracoskinolina Moullade (see emended genus diagnosis of Arnaud-Vanneau, 1980). Although nothing is known about the embryo and the internal structure displayed in transverse sections, this taxon lacks horizontal partitions and has been tentatively transferred to Cribellopsis Arnaud-Vanneau by Yazdi-Moghadam and Schlagintweit (2021). The form described as Dictyoconus walnutensis (Carsey) subspecies pyrenaicus by Moullade and Peybernès (1975) from the lower-middle Albian of northern Spain is similar to the Campanian species from Greece to some extent (e.g. dimensions, one rafter). Schroeder (1985) clarified that this Spanish taxon does not belong to Dictyoconus Blanckenhorn because of the aligned pillars in the former. In addition, Schroeder (1985, p. 46) concluded that "Dictyoconus" pyrenaicus should be transferred to Paracoskinolina or an allied form due to the aligned pillars and foramina. In fact, the transverse section provided by Moullade and Peybernès (1975, pl. 1, fig. 1) nicely shows the concentric arrangement of the foramina, a diagnostic feature of the Dictyorbitolininae sensu Schroeder in Schroeder et al. (1990). Some morphological differences, such as a more inflated test and differing apical angle (50-70 degrees, acc. to Schroeder, 1985), of Paracoskinolina pyrenaicus (Moullade and Peybernès) comb. nov. are worth mentioning.

Comparisons: The new species has been described and illustrated by Fleury (1970) as Dictyoconus sp. Contrasting with Paracoskinolina Moullade, Dictyoconus Blanckenhorn has pillars in the central zone that alternate in position between subsequent chambers (e.g., Davies, 1930, 1939; Arnaud-Vanneau, 1980; Loeblich and Tappan, 1987). Having a single rafter in the chamber marginal zone, $P$. klokovaensis can be compared with $P$. arcuata Arnaud-Vanneau, 1976 and $P$. reicheli (Guillaume, 1956) (Fig. 6). P. arcuata is morphologically different with its cylindro-conical test also displaying larger dimensions (e.g., height $>3 \mathrm{~mm}$ ) (Arnaud-Vanneau, 1976, 1980). $P$. reicheli (Guillaume) is slightly larger as $P$. klokovaensis and with up to four intercalary beams (e.g. Guillaume, 1956, pl. 1, fig. 6), its marginal zone is more complex. The other species, P. maynci (Chevalier, 1961), P. sunnilandensis (Maync, 1950), and P. coogani Scott, 2002 lack rafters in the marginal zone. Note that many other "Paracoskinolina" have already been taxonomically revised or are still in need of revision (e.g., Cherchi and Schroeder, 1982; Schlagintweit, 2020; Yazdi-Moghadam, 2021). These include those described before the taxonomic clarification of the genus provided by Arnaud-Vanneau (1980).

Biostratigraphy: The levels with "Orbitolinidés K" (for Klokova) have been placed into the upper SantonianLower Campanian (Fleury, 1980, fig. 8, p. 44). Fleury (1980) respectively established a zone "Cs B 5 à "Orbitolinidés K" et Montcharmontia apenninica s.s." In some sections, these orbitolinids appear some metres above the 


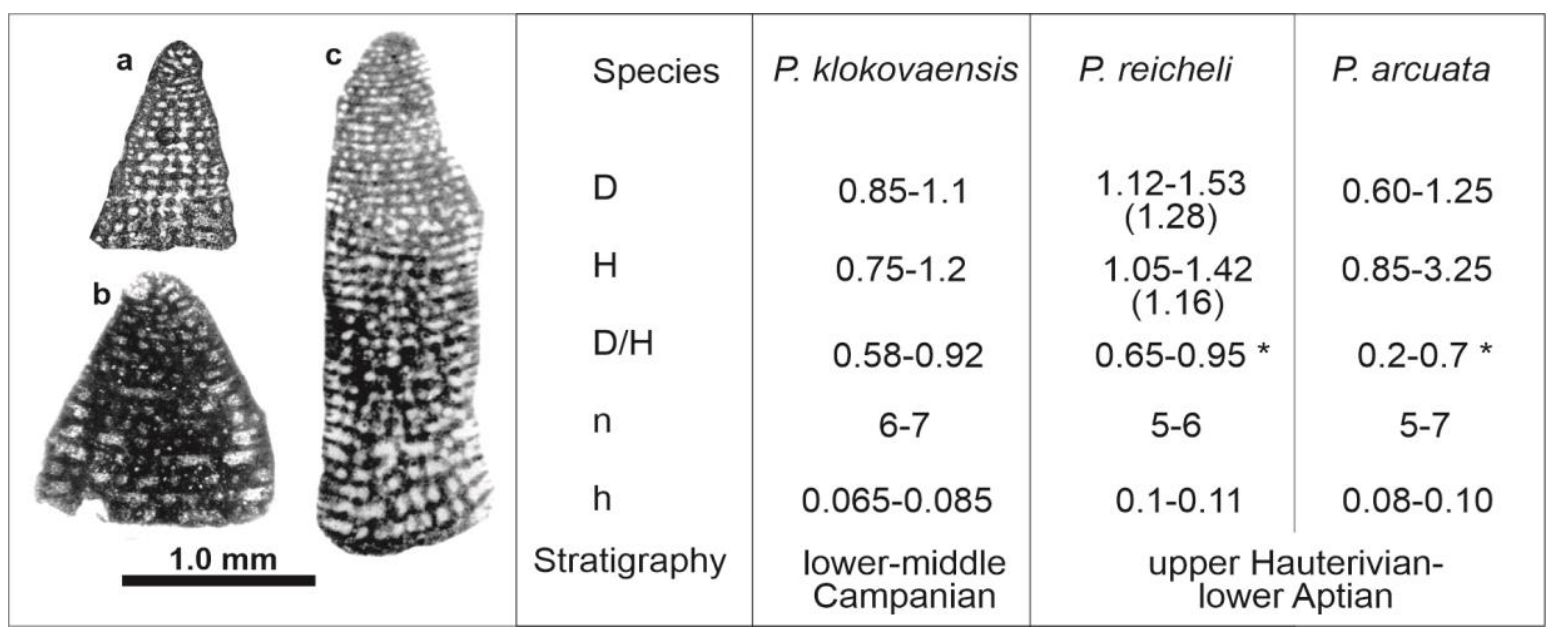

Fig. 6 Comparison of Paracoskinolina species with one horizontal partition in the marginal zone: a P. klokovaensis sp. nov., b $P$. reicheli Guillaume, 1956. c $P$. arcuata (Arnaud-Vanneau 1976). $\mathrm{D}=$ test diameter, $\mathrm{H}=$ test height, $\mathrm{n}=$ number of chambers per last $0.5 \mathrm{~mm}$ axial length, $\mathrm{h}=$ chamber height (all data except $\mathrm{D} / \mathrm{H}$ in $\mathrm{mm}$ ). * measured from original illustrations. Stratigraphy of the two Lower Cretaceous species according to Clavel et al. (2014).

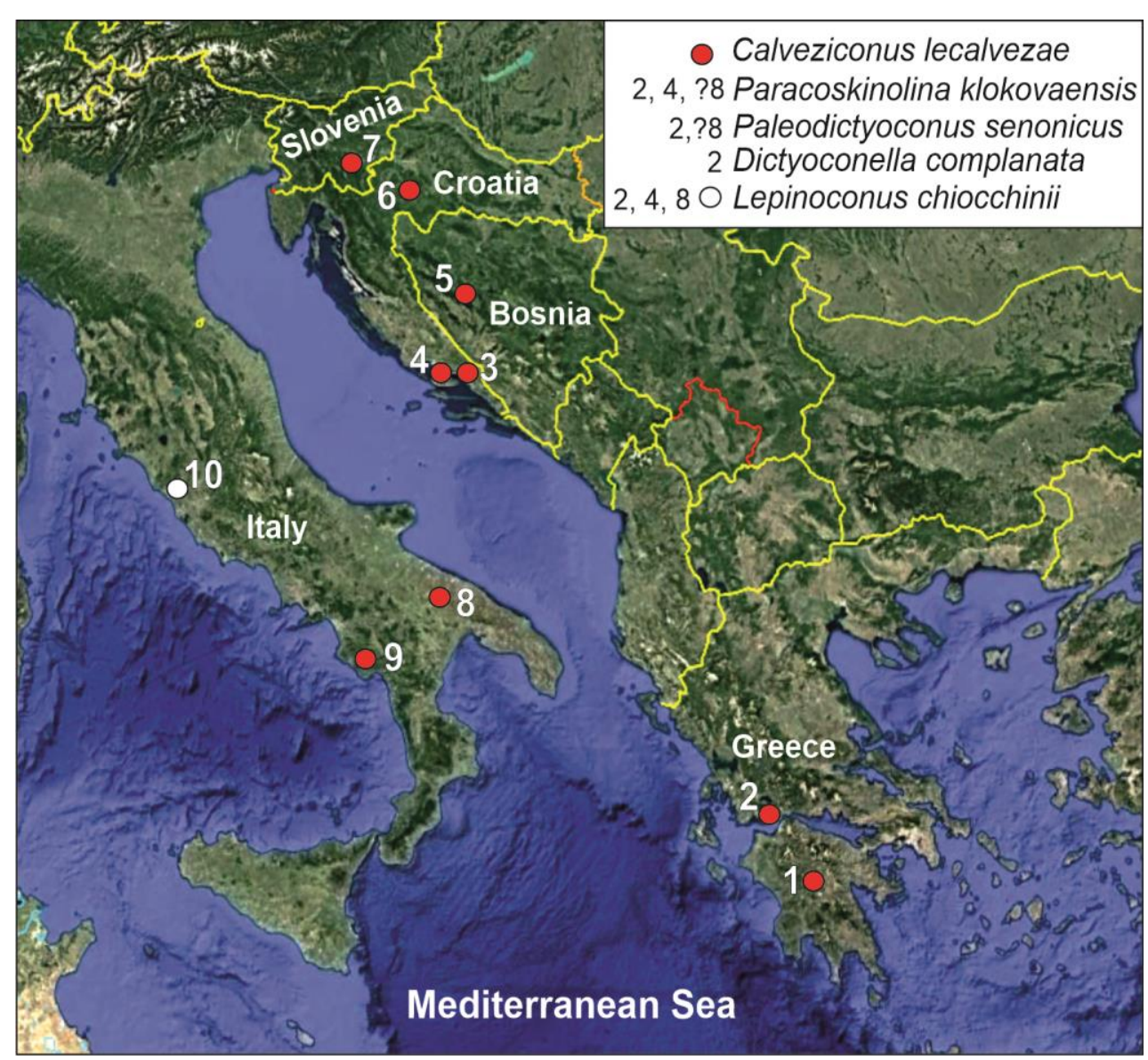

Fig. 7 Central Mediterranean area (modified from Google Earth) with occurrences of Campanian Orbitolinidae-Coskinolinidae. 1: Zambetakis-Lekkas and Alexopoulos (2007) 2: Fleury (1970, 1980, this work) 3: Mount Biokovo (Sokač et al., 2012) 4: Brač Island (Gušić and Jelaska, 1990; CvetkoTešović et al., 2001) 5-7: Moro et al. (2016) 8: Luperto-Sinni (1976) 9: Frijia et al. (2015) 10: CruzAbad et al. (2017). 
LAD of Murgella lata Luperto Sinni and Keramosphaera tergestina (Stache) (Fleury, 1980, figs. 18 and 30) while in others (including the material studied herein) M. lata and the first Orbitolinids display overlapping ranges (op. cit., Fig. 25). Lepinoconus chiocchini was reported within a rather short interval at its type-locality in southern Italy, "bracketed between the $K$. tergestina level....and the upper limit of the S. mediterranea subzone", that is lower Campanian. With this data, the Orbitolinid levels of Klokova Mountain can be assigned to the uppermost lower-middle Campanian (see Fig. 15 in Frijia et al., 2015: SIS data; Cruz-Abad et al., 2017; Villalonga et al., 2019).

\section{DISCUSSION}

The genus Paracoskinolina was so far recorded from the upper Berriasian (Bucur et al., 2020) to the middle-upper Albian interval (Maync, 1955; Scott, 2002). The occurrence of an individual species in the Upper Cretaceous was already reported for the genera Falsurgonina Arnaud-Vanneau, 1980 (F. parva Luperto Sinni \& MartinChivelet), Orbitolinopsis Henson, 1948 (O. senonicus Gendrot, 1968), and Paleodictyoconus Moullade, 1965 (P. senonicus Moullade \& Viallard, 1973). As already noted previously, also Calveziconus Caus \& Cornella, 1982 might belong to this group, showing striking similarities with the lower Aptian Iraqia Henson. Concerning Orbitolinopsis senonicus, Gendrot (1968, p. 680) noted the presence of a pseudo-keriothecal wall structure sensu Douglass (1960) visible only in extreme thin thinsections. Poorly discernible in the detailed view provided by Gendrot (1968, pl. 6, fig. 6), such a feature has so far not been described from any other species of the genus (e.g., Arnaud-Vanneau, 1980). The four species appear several million years after the larger benthic foraminifera extinction event associated with the Cenomanian - Turonian boundary anoxic/eutrophication event (e.g., Parente et al., 2008). This phenomenon of "reappearance" after longer gaps (or "ghost ranges"; Wills, 2007) may be related to morphological convergence (homeomorphism) (see also Elvis taxa; Fara, 2001) or iterative evolution reflecting common functional constraints. The repeated evolution of peculiar shell morphologies (e.g., digitate) for example are known from planktonic foraminifera during the Cretaceous and Cenozoic (Coxall et al., 2007). Iterative evolution as the main mode of morphological variation in Mesozoic imperforate larger benthic foraminifers has been recently discussed by Septfontaine (2020). This phenomen appears to be present also in the longlasting and complex history of the Orbitolinidae stretching from the upper Berriasian to the Paleogene (lower Oligocene) including two main-mass extinctions $(\mathrm{Ce} / \mathrm{T}$ and $\mathrm{K} / \mathrm{T}$ ). The functional significance of individual test morphologies and structures in the Orbitolinidae (e.g., Hottinger and Drobne, 1980) is poorly constrained and needs further studies.
The distribution pattern of the conical agglutinated taxa reported from the Upper Cretaceous of Greece herein within the Central Mediterranean realm is shown in figure 7. The occurrence of comparable assemblages seems to be characteristic for distinct levels in the lower-middle Campanian of the Adriatic-Dinaridic Carbonate Platform (Italy, Slovenia, Bosnia, Croatia, Greece).

\section{CONCLUSIONS}

The taxonomic assessment of the assemblage of conical agglutinated foraminifera (Coskinolinidae, Orbitolinidae) from the Gavrovo-Tripolitza Platform of the external Hellenides (Greece), first described by Fleury (1970) demonstrates that the following taxa are present: Lepinoconus chiocchinii Cruz-Abad, Consorti \& Caus, Paleodictyoconus cf. senonicus Moullade \& Viallard, Calveziconus lecalvezae Caus \& Cornella, Dictyoconella complanata Henson, and Paracoskinolina klokovaensis n. sp. The age of this assemblage can be revised to the uppermost lower-middle Campanian. Paracoskinolina klokovaensis represents the first record of the genus Paracoskinolina Arnaud-Vanneau in the Upper Cretaceous, thus representing either a survivor of the CenomanianTuronian boundary extinction or the reappearance of a peculiar morphological trait. Displaying a comparably complex exoskeleton (one rafter and several orders of intercalary beams), P. klokovaensis can be considered a rather advanced (or complex) representative of the genus. The occurrence of comparable assemblages of agglutinated conical larger benthic foraminifers seems to be characteristic for distinct levels in the lower-middle Campanian of the Adriatic-Dinaridic Carbonate Platform (Italy, Slovenia, Bosnia, Croatia, Greece).

\section{ACKNOWLEDGEMENTS}

Jean-Jacques Fleury (formerly Université des Sciences et Techniques de Lille) provided the thin sections for this study also giving the permission for their storage. Ioan Bucur (Cluj-Napoca) kindly made the microphotographs. Without the assistance of both, the present study would not have been possible. The two reviewers Mike Simmons (London) and Simon Mitchell (Kingston) provided helpful remarks. Thin sections from the Campanian of Brač Island, Croatia have temporarily been borrowed from Blanka Cvetko-Tesovič (Zagreb) which is gratefully acknowledged.

\section{REFERENCES}

Arnaud-Vanneau, A., 1976. Etude de l'évolution Barrémo-Bédoulienne d'un Orbitolinidè urgonien Dictyoconus maynci (Chevalier) et description d'une nouvelle sous-espèce: Dictyoconus maynci arcuatus. Revista Española de Micropaleontolgía, 3 (1): 5-14. 
Arnaud-Vanneau, A., 1980. L’Urgonien du Vercors septentrional et de la Chartreuse. Géologie Alpine Mémoire, 11 (3 volumes): 874 p.

Aubouin J., Brunn J.H. \& Celet P., 1958. Les massifs du Klokova et Varassova (Akarnanie), Annales Géologiques de Pays Helléniques. Geological Society of Greece, 9: 256-59.

Bernier, P. \& Fleury, J.-J., 1980. La plate-forme carbonatée de Gavrovo-Tripolitza (Grèce): Évolution des conditions de sédimentation au cours du Mésozoïque. Géologie Méditerranéenne, 7 (3): $247-$ 259.

Bilotte, M., 1974. Contribution á l' étude du Sénonien sud-Pyrénéen. 1. Stratigraphie du Massif de Rasos de Peguera. Abrardia catalaunica n. sp. Orbitolinidae nouveau du Campanien et du Maestrichtian. Bulletin de la Societé d' Histoire Naturelle de Toulouse, 110: 300-307.

Bilotte, M., 1985. Le Crétacé supérieur des plates-formes est-pyrénéennes. Strata, Toulouse, sér. 2, 5: 1-438.

Blanckenhorn, M., 1900. Neues zur Geologie und Paläontologie Ägyptens. Zeitschrift der Deutschen Geologischen Gesellschaft, 52: 403-479.

Bucur, I.I., Sudar M., Schlagintweit F., Pleş G., Săsăran E., Jovanović D., Polavder S. \& Radoičić, R., 2020. Lowermost Cretaceous limestones from the Kučaj zone (Carpatho-Balkanides, Eastern Serbia): new data on their age assignment. Cretaceous Research, 116, article 104575.

Carter, H.J., 1861. Further observations on the structure of Foraminifera and on the larger fossilized forms of Sind, etc. Journal of the Bombay Branch of the Royal Asiatic Society, 6: 31-76.

Caus, E. \& Cornella, A., 1982. Calveziconus lecalvezae n. gen. n. sp., Orbitolinidé Campanien de la bordure méridionale des Pyrénées. Cahiers de Micropaléontologie, 4: 27-34.

Caus, E., Rodes, D. \& Solé Sugrañes L.L., 1988. Bioestratigrafía y estructura del Cretácico superior de la Vall d'Alinyà (Pirineo oriental, prov. De Lleida). Acta Geològica Hispànica, 23 (2): 107-118.

Cherchi, A. \& Schroeder, R., 1982. Sobre la edad de Ia transgresion Mesocretacica en Asturias. Cuadernos de Geologia Iberica, 8: 219-233.

Chevalier, J., 1961. Quelques nouvelles espèces de Foraminifères dans le Crétacé inférieur méditerranéen. Revue de Micropaléontologie, 4 (1): 30-36.

Clavel, B., Charollais, J., Busnardo, J., Granier, B., Conrad, M., Desjacques, P. \& Metzger, J., 2014. La plateforme carbonatée urgonienne (Hauterivien supérieur Aptien inférieur) dans le Sud-est de la France et en Suisse: Synthèse. Archives des Sciences, 67, 1-100.

Coxall, H.K., Wilson, P. A., Pearson, P.N. \& Sexton, P.F., 2007. Iterative evolution of digitate planktonic foraminifera. Paleobiology, 33 (4): 495-516.

Cruz-Abad, E., Consorti, L. \& Caus, E., 2017. Lepinoconus chiocchinii gen. n., sp. n., a conical agglutinated foraminifera from the Upper Cretaceous of Ita- ly. Rivista Italiana di Paleontologia e Stratigrafia, 123 (2): 347-354.

Cvetko-Tešović, B., Gušić, B., Jelaska, V. \& Bucković, D., 2001. Stratigraphy and microfacies of the Upper Cretaceous Pučišća Formation, Island of Brač, Croatia. Cretaceous Research, 22: 591-613.

Davies, L.M., 1930. The genus Dictyoconus and its allies: A review of the group, together with a description of three new species from the Lower Eocene beds of northern Baluchistan. Transactions of the Royal Society of Edinburgh, 56, part II (no. 20): 485-505.

Davies, L.M., 1939. An early Dictyoconus, and the genus Orbitolina: their contemporaneity, structural distinction, and respective natural allies. Transactions of the Royal Society of Edinburgh, 59, 773-790.

Decrouez, D. \& Moullade, M., 1974. Orbitolinidés nouveaux de l'Albo-Cénomanien de Grèce. Archives des Sciences, 27 (1): 75-92.

Fara, E. 2001. What are Lazarus taxa? Geological Journal, 36: 291-303.

Fleury, J.J., 1970. Le Sénonien et l'Eocène à microorganismes benthoniques du Klokova (zone du Gavrovo, Akarnanie, Grèce continentale). Revue de Micropaléontologie, 13 (1): 30-44.

Fleury J.J., 1980. Les zones de Gavrovo-Tripolitza et du Pinde-Olonos (Grèce continentale et Péloponnèse du Nord. Evolution d'une plate-forme et d'un bassin dans leur cadre alpin. Société Géologique du Nord, 4: 1-651.

Fleury, J.J., 1984. Senalveolina aubouini n. gen. n. sp., Alveolinidae nouveau du Sénonien de Grèce Senalveolina aubouini n. gen., n. sp., a new Alveolinidae of Greek Senonian. Revue de Micropaléontologie, 27: 171-188

Frijia, G., Parente, M., Di Lucia, M. \& Mutti, M., 2015. Carbon and Strontium isotope stratigraphy of the Late Cretaceous (Cenomanian-Campanian) shallowwater carbonates of southern Italy: chronostratigraphic calibration of larger foraminifera biostratigraphy. Cretaceous Research, 53: 110-139.

Gendrot, C., 1968. Stratigraphie et micropaléontologie du Sénonien de la région es Martigues près Marseille (Bouches-du-Rhône). Eclogae Geologicae Helvetia, 61(2): 657-694.

Gräfe, K.-U., 2005. Late Cretaceous foraminifers from the Basque-Cantabrian Basin, northern Spain. Journal of Iberian Geology, 31 (2): 277-298.

Granier, B., Clavel, B., Moullade, M., Busnardo, R., Charollais, J., Tronchetti, G. \& Desjacques, P., 2013. L'Estellon (Baronnies, France), a "Rosetta Stone" for the Urgonian biostratigraphy. Carnets de Géologie/Notebooks in Geology, Article 2013/04 (CG 2013_A04), 139-183.

Gušić, I. \& Jelaska, V., 1988. Foraminiferal assemblages, facies, and environments in the Upper Cretaceous of the Island of Brac, Yugoslavia. Revue de Paléobiologie vol. spec. 2 Benthos '86: 447-456. 
Gušić, I. \& Jelaska, V., 1990. Upper Cretaceous stratigraphy of the Island of Brač. Djela Jugosl Akad Znanosti Umjetnosti Zagreb, 69: 1-160.

Guillaume, H., 1956. Une nouvelle espèce Crétacé du genre Dictyoconus Blanckenhorn. Eclogae Geologicae Helvetiae 49 (1): 141-146.

Henson, F.R.S., 1948. Larger imperforate Foraminifera of south-western Asia. Families Lituolidae, Orbitolinidae and Meandropsinidae. Monograph British Museum (Natural History), 127 pp.

Hottinger, L. \& Drobne, K., 1980. Early Tertiary conical imperforate foraminifera. Razprave IV. razr. SAZU, 22: $188-276$.

Kaminski, M.A., 2014. The year 2010 classification of the agglutinated foraminifera. Micropaleontology, 60(1): 89-108.

Lamarck, J.B.P.A., de, 1804. Mémoires sur les fossiles des environs de Paris. Ann. Mus. Natl. Hist. Natur. Paris, 5: 177-180.

Loeblich, A.R., Jr. \& Tappan, H., 1987. Foraminiferal genera and their classification, Van Nostrand Reinhold, New York, 2 vol., 970 pp., 847 pls.

Luperto Sinni, E., 1976. Microfossili senoniani della Murge. Rivista Italiana di Paleontologia e Stratigrafia, 82 (2): 293-416.

Luperto Sinni, E. \& Martin-Chivelet, X., 1999. Falsurgonina parva, nuova specie di Foraminifero del Santoniano di Bocairente (SE della Spagna). Geologica Romana, 35: 261-167.

Mavrikas, G., 1993. Évolution Crétacée-Éocène d'une plate-forme carbonatée des Hellénides externes - La plate-forme des Ori Valtou ("Massif du Gavrovo") Zone de Gavrovo-Tripolitza, Grèce Continentale. Société géologique du Nord, publication 70: 1-239.

Maync, W., 1955. Coskinolina sunnilandensis n. sp., a lower Cretaceous (Urgo-Albien) species.

Contributions from the Cushman Foundation for Foraminiferal Research, 6 (3): 105-111.

Molina, E., Alegret, L., Serra Kiel J., 2013. Los microfósiles del Prepirineo de Arguis (Huesca): breve guía para observarlos y reconocerlos. Naturaleza Aragonesa, 30: 4-12.

Moro, A., Horvat, A., Tomić, V., Sremac, J. \& Bermanec, V., 2016. Facies development and paleoecology of rudists and corals: an example of Campanian transgressive sediments from northern Croatia, northeastern Slovenia, and northwestern Bosnia. Facies, 62 (19): 1-25.

Moullade, M., 1965. Contribution au problème de la classification des Orbitolinidae (Foraminiferida, Lituolacea). Comptes rendus hebdomadaires des séances de l'Académie des sciences, 260: 4031-4034.

Moullade M., 1966. Étude stratigraphique et micropaléontologique du Crétacé inférieur de la "fosse vocontienne". 1er fascicule. Documents des Laboratoires de Géologie de la Faculté des Sciences de Lyon, 15: 1217.
Moullade, M. \& Peybernès, B., 1975. Biozonation par Orbitolinidés du Clansayesien et de l'Albien calcaires des Pyrénées franco-espagnoles. Comptes Rendus de l'Académie des Sciences, Sér. D, 280: 2529-2532.

Moullade, M. \& Viallard, P., 1973. Paleodictyoconus senonicus n. sp., a new orbitolinid from the upper Cretaceous of the Iberian Cordillera, Spain. Archives des Sciences, 25 (3): 335-342.

Neumann, M., 1978. Contribution à l'étude du genre Pseudorbitolina Douvillé 1919 (Foraminifère). Revue de Micropaléontologie, 20 (4): 197-205.

Nirta, G., Aberhan, M., Bortolotti, V., Carras, N., Menna, F. \& Fazzuoli, M., 2020. Deciphering the geodynamic evolution of the Dinaric orogen through the study of the "overstepping" Cretaceous successions. Geological Magazine, 157 (8): 1238-1264.

Orbigny, A.D. d'., 1839. Foraminifères, in de la Sagra R., Histoire physique, politique et naturelle de l'ile de Cuba. A. Bertrand: 1-224.

Parente, M., Frijia, G., Di Lucia, M., Jenkyns, H.C., Woodfine, R.G. \& Baroncini, F., 2008. Stepwise extinction of larger foraminifera at the CenomanianTuronian boundary: a shallow-water perspective on nutrient fluctuations during Oceanic Anoxic Event 2 (Bonarelli Event). Geology, 36: 715-718.

Pawlowski, J., Holzmann, M. \& Tyszka, J., 2013. New supraordinal classification of Foraminifera: Molecules meet morphology. Marine Micropaleontology, 100: 1-10.

Pleničar, M. \& Šribar, L., 1992. Le récif de rudistes près de Stranice (N.O. de la Yugoslavie). Geologica Romana, 28: 305-317.

Schlagintweit, F., 2020. Cribellopsis moulladei (SaintMarc, 1974) nov. comb. (Foraminiferida, Orbitolinidae): An Albian marker taxon of the Southern Neotethysian Margin. Acta Palaeontologica Romaniae, 16 (1): 37-41.

Schlagintweit, F.\& Rashidi, K., 2021. Dictyoconella Henson, 1948, Upper Cretaceous Larger Benthic Foraminifera: A taxonomic revision with the establishment of Gusicella gen. nov. (type-species Dictyoconella minima Henson). Acta Palaeontologica Romaniae, 17 (2): 3-13.

Schlagintweit, F., Rashidi, K. \& Babadipour, M., 2016. Orbitolinid foraminifera from the Late Maastrichtian of the Tarbur Formation (Zagros Zone, SW Iran). Acta Palaeontologica Romaniae, 12 (2): 29-46.

Schlumberger, C. \& Douvillé, H., 1905. Sur deux foraminifères éocènes. Dictyoconus egyptiensis Chapm. et Lituonella roberti nov. gen. et sp. Bulletin de la Société géologique de France, (série 4) 5 (3): 291-304.

Schroeder, R., 1985. "Dictyoconus" pyrenaicus Moullade \& Peybernès, 1975. In: Schroeder, R., Neumann, M. (cords.), Les grands Foraminifères du Crétacée Moyen de la region méditerranénne. Geobios, Mémoire special, 7: 44-46. 
Schroeder, R., Clavel, B. \& Charollais, J., 1990. Praedictyorbitolinina carthusiana $\mathrm{n}$. gen., n. sp., Orbitolinidé (Foraminiferida) de la limite HauterivienBarrémien des Alpes occidentales. Paläontologische Zeitschrift, 64 (3/4): 193-202.

Schroeder, R. \& Neumann, M. (coords.). Les Grands Foraminifères du Crétacé Moyen de la région Méditerranénne. Géobios, Mémoire Special, 7: 1-161.

Schubert, R., 1912. Über Lituonella und Coskinolina liburnica Stache sowie deren Beziehungen $\mathrm{zu}$ den anderen Dictyoconinen. Jahrbuch der kaiserlichköniglichen geologischen Reichsanstalt, 62: 195-208.

Scott, R.W., 2002. Upper Albian benthic foraminifers new in West Texas. Journal of Foraminiferal Research, 32: 43-50.

Septfontaine, M., 2020. Steps of Morphogenesis and Iterative Evolution of Imperforate Larger Foraminifera in Shallow Carbonate Shelves during Mesozoic times: Possible Relations to Symbiotic and Abiotic Factors (Chapter 8). In: Guex. J., Torday, J.S. \& Miller, W.B. Jr. (eds) Morphogenesis, Environmental Stress and Reverse Evolution. Berlin, Springer Nature, pp. 129174.

Serra-Kiel, J., Gallardo-Garcia, A., Razin, Ph., Robinet, J., Roger, J., Grelaud, J., Leroy, S. \& Robin, C., 2016. Middle Eocene-Early Miocene larger foraminifera from Dhofar (Oman) and Socotra Island (Yemen). Arabian Journal of Geoscience, 9: 344.

Sha, J., Fabbi, S., Cestari, R. \& Consorti, L., 2020. Stratigraphic and taxonomic considerations on the Late Cretaceous rudist fauna of Aksai Chin (Western Tibet, China) from the De Filippi Collection. Carnets de Géologie, 20 (13): 249-272.

Silvestri, A., 1931. Sul genere Chapmanina e sulla Alveolina maiellana $\mathrm{n}$. sp. Bollettino della Società Geologica Italiana, 50: 63-73.

Stache, G., 1875. Neue Beobachtungen in den Schichten der liburnischen Stufe. Verhandlungen der Geologischen Reichsanstalt 1875: 334-338.
Sokač, B., Velič, I., Grgasovič, T., Ćosović, V. \& Vlahović, I., 2012. Taxonomy and stratigraphy of fan algal assemblage in Paleogene deposits of the northern foothill of Mt. Biokovo (Southern Croatia). Geologia Croatica, 65 (2): 161-205.

Velić, I., 2007. Stratigraphy and palaeobiogeography of Mesozoic benthic foraminifera of the Karst Dinarides (SE Europe). Geologia Croatica, 60: 1-113.

Vicedo, V., Berlanga, J.A. \& Serra-Kiel, J., 2014. Paleocene larger foraminifera from the Yucatán Peninsula (SE Mexico). Carnets de Géologie/Notebooks on Geology, 14 (4): 41-68.

Villalonga, R., Boix, C., Frijia, G., Parente, M., Bernaus, J.M. \& Caus, E., 2019. Larger foraminifera and strontium isotope stratigraphy of middle Campanian shallow-water lagoonal facies of the Pyrenean Basin (NE Spain). Facies, 65: 20.

Whittaker, J.E., Jones, R.W. \& Banner, F.T., 1998. Key Mesozoic Benthic Foraminifera of the Middle East. The Natural History Museum, London: 1-237.

Wills, M.A., 2007. Fossil ghost ranges are most common in some of the oldest and some of the youngest strata. Proceedings of the Royal Society B, 274: 2421-2427.

Yazdi-Moghadam, M. \& Schlagintweit, F., 2021. Cenomanian "orbitoliniform" foraminifera - State of the art and description of Ebrahimiella dercourti (Decrouez and Moullade, 1974) gen. and comb. nov. (family Coskinolinidae) from the Sarvak Formation (SW Iran, Zagros Zone). Cretaceous Research,

Zambetakis-Lekkas, A. \& Alexopoulos, A., 2007. Field Trip A6 Evolution of a carbonate platform. A case study in the Gavrovo-Tripolitza Zone. $25^{\text {th }}$ IAS Meeting of Sedimentology, 2007 Patras, Greece, pp. 63-76.

Zelic, M., Marroni, M., Pandolfi, L. \& Trivić, B., 2010. Tectonic setting of the Vardar Suture Zone (DinaricHellenic Belt): The example of the Kopaonik Area (Southern Serbia). Ofioliti, 35 (1): 49-69. 